\title{
Is Competition Law an Impediment to CSR?
}

\author{
Wim Dubbink \\ Frans Paul van der Putten
}

\begin{abstract}
This paper provides an empirical case study of the relationship between corporate social responsibility (CSR) and the new competition regulation in the Netherlands. The leading question in this case study is whether the new institutional arrangement has allowed for the possibility that reasonable exceptions can be made to the principle that inter-firm cooperation is prohibited. That is to say: does the new institutional arrangement allow for the possibility of 'well organized but not 'perfect' markets'? The investigation focuses on the Netherlands, which constitutes an exemplary case as the Dutch are committed to both strengthen the competitiveness of the market and allow for exceptions on behalf of non-economic values such as CSR. The authors expect that the Dutch context will prevent a doctrinal and categorical rejecting of any good argument to make an exception to the rule that inter-firm cooperation must be prohibited.
\end{abstract}

KEY WORDS: competition law, corporate social responsibility, CSR, inter-firm cooperation, Netherlands competition authority, supply chain responsibility

\section{Introduction}

This paper provides an empirical case study of the relationship between corporate social responsibility (CSR) and the new competition regulation in the Netherlands. The new law is devoted to the realization of competitive markets and assigns the task to oversee possible breaches of the law to the Netherlands Competition Authority (NMa). It is an important assumption of the law that inter-firm cooperation will decrease competitiveness. Prohibition of any inter-firm cooperation therefore is one of the principle ways in which competitiveness is secured. The leading question in this case study is whether the new institutional arrangement has allowed for the possibility that reasonable exceptions can be made to the principle that inter-firm coop- eration is prohibited. That is to say: does the new institutional arrangement allow for the possibility of 'well organized but not 'perfect' markets'? This case study derives its relevance from the ongoing discussion within the context of theorizing on CSR on the feasibility or even the possibility of CSR, as this phenomenon seems to presuppose inter-firm cooperation - at least on competitive markets. In order to situate the case study we will start by providing a brief sketch of this discussion.

Ever since its inception as a theoretical and practical concept, CSR is surrounded by a major concern: Is it possible or feasible on a well-organized market, given that a well-organized market is competitive and therefore will leave very little discretion to suppliers? The concern is for example voiced by Cottrill (1990, p. 725): 'You can have CSR or competition, but not both'. The concern can be given a theoretical backing by means of neoclassical economic theory (See for example Baumol, 1975; Baumol and Batey Blackman, 1991; Dubbink, 2003). Neo-classical economic theory conceptualizes a well-organized market as a 'perfect market'. A perfect market is characterized by perfect competition. Perfect competition means that all parties are price takers (Hayek, 1980). In their rivalry for market share the competing parties are so pressed by the hard discipline of the market that none of the parties can influence the market price. This price is at its lowest possible level. Consequently, the market parties do not have any discretion or freedom of action to mould the market process. Ideally, each market actor makes just enough money to cover all costs, thereby maximizing the consumer surplus. This has major consequences for the possibility of CSR. Following Carroll we define CSR as the moral obligation of business entities 'to pursue those policies, to make those decisions, or to follow those lines of 
action which are desirable in terms of the objectives and values of [...] society' (Carroll, 1999, p. 270). ${ }^{1}$ Pursuing those policies will somehow always involve costs. CSR therefore is impossible on a perfect market. By definition, market actors cannot cover the costs involved and thus cannot make room for the necessary discretion. A subsequent conclusion that many critics of CSR draw on the basis of this argument is that CSR only appears on imperfect markets. Market actors have some discretion on these markets, since - by definition - imperfect markets are markets in which actors do have some power to influence prices.

How have scholars in favour of CSR reacted to the charge that CSR is only possible on markets that are not well organized? Often it is argued that in fact all actually existing markets are to some extent imperfect. A disadvantage of this strategy is that CSR is necessarily depicted as a marginal, second best phenomenon. This is one of the reasons why van Luijk (2000) argues that the response by CSR protagonists has been insufficient. According to him, business ethics as a discipline has ignored or at least neglected the institutional aspects and limits of moral conduct in a free market. However, even if generally true, there have been some business ethics scholars who have tried to take into account the institutional side of market morality. Jeurissen and van der Ven (2005 and 2006; see also: Dubbink, 2003) are an example. They add a fundamental argument to the position that CSR is possible because of the imperfection of all actual existing markets. Basically, Jeurissen and van der Ven reject the Neo-classical conception of the free market. That is to say: even though Jeurissen and van der Ven acknowledge both that individual companies hardly have any room for manoeuvre on markets with fierce competition and that fierce competition is in principle a good thing, they do not dismiss the concept of CSR as impractical for that reason. Their solution is that 'the principle of moral displacement' (De George, 1999, p. 97) should be applied to this case. This principle acknowledges that moral actors may be confronted with collective action problems, while trying to meet their moral responsibilities. According to the principle, actors should organize their responsibility at the right level in order to meet their moral responsibilities. In the context of contemporary markets, this level will most likely be the industry level. It is important to note that the principle of moral displacement is not meant to generally halt competition. According to the principle, competition must only be tempered exactly at those places where competition causes external effects.

To see why this suggestion by Jeurissen and van der Ven goes against the grain of Neo-classical economic thinking it must be understood that the authors in fact make a radical conceptual move. They distinguish between the concept of a perfect market and the concept of a well-organized market. A well-organized market is a market that is competitive to such an extent that the advantages of organizing an economy as a market are sufficiently realized. (Some of these advantages are for example adequate allocation of the means of production, a great consumer surplus, and innovation.) Next to that, a wellorganized market also is conducive to realizing a well-organized society. ${ }^{2}$ The 'perfect market' is the Neo-classical instantiation of that concept. However, as Jeurissen and van der Ven seem to argue, it is not necessarily the only or the best instantiation. According to them a market is better organized if it is sufficiently competitive but also leaves some room for discretion and thus CSR.

Another way to formulate the radical nature of the proposal by Jeurissen and van der Ven is in terms of the need for or prohibition of inter-firm cooperation. Jeurissen and van der Ven hold that on competitive markets CSR is only possible if there is some form of inter-firm cooperation. ${ }^{3}$ Without such cooperation, firms cannot afford the costs involved in CSR. Jeurissen and van der Ven hold that some forms of inter-firm cooperation need not necessarily block the competitiveness of the market. This suggestion is incompatible with the Neo-classical assumption that, on a perfect market, actors work in complete isolation from each other. Isolation guarantees competitiveness. Within Neo-classical thinking, market actors are thus not allowed to come into contact with one another and thus make arrangements of any kind. Any sort of arrangement could result in some form of discretion. Inter-firm cooperation of any kind thus is barred. Because of their concern for CSR, Jeurissen and van der Ven break with the absolute prohibition against inter-firm cooperation. They suggest that some kinds of interfirm cooperation will not damage a well-organized market. A well-organized market is not necessarily the same as a perfect market in the Neo-classical sense. 
In the context of this paper, it is important to understand why Neo-classical thinking has such a deep distrust against inter-firm cooperation. In fact, the distrust against inter-firm cooperation precedes Neo-classical thinking and at least goes back to the days of Adam Smith. Smith (1776, book 1, chapter 10) famously remarked that 'people of the same trade seldom meet together, even for merriment and diversion, but the conversation ends in a conspiracy against the public'. In a recent paper Kimman (2006, pp. 165-167) points at one of the important reasons that might feed this distrust. Interestingly, Kimman acknowledges that CSR depends on inter-firm cooperation. In his view CSR is only possible if competitors are allowed to contribute collectively to setting the norms for competition. ${ }^{4}$ However, then he makes the point that the distinction between a trust aimed at limiting competition and an industry association aimed at environmental protection is a matter of perspective. What is judged positively by one party may be seen as undesirable by another. That is to say: inter-firm cooperation cannot be allowed for on a well-organized market because there are no reasonable, let alone objective, criteria by means of which we can distinguish reasonable exceptions from unreasonable ones. Since it is all 'a matter of perspective' the risk is simply too big that we are only serving some partisan business interest, cleverly disguised as a CSR initiative. Thus we are confronted with an either/or decision: either we lock out any form of inter-firm cooperation (and accept the possible disadvantages of that decision because the advantages are much bigger) or we will end up in the swamp of exceptions and subjective arguments that will in the end disrupt the working of the competitive free market system. In terms of an example: in the chicken industry, where competition is fierce, we cannot allow chicken farmers to make any kind of collective arrangement in the interest of animal welfare. It is principally impossible to distinguish a sincere proposal that in fact only helps the chickens from an insincere one that in fact cuts out competition.

This study tries to follow up on this discussion. It wants to make a modest contribution to answering the question whether we are indeed confronted with an either/or decision in this matter. Is it possible to allow for exceptions to the principle that inter-firm cooperation must be prohibited on a well-organized market? Is it possible to find reasonable principles and the make reasonable judgements in cases at hand and thus reasonably distinguish business efforts to help the public from business efforts to conspire against the public? We think that finding an answer to this question is important, given two opposing contemporary tendencies in thinking on the free market system. On the one hand we are confronted with the need for markets that are fiercely competitive; on the other hand we are confronted with the increasing need for business to take a role in governance (see for example: Scherer et al., 2006). Latter-day discussions and studies in the context of the WTO underline the global importance of the issue (Vedder, 2003). In this context we need to know whether well organized (i.e., fiercely competitive) but not 'perfect markets' are possible.

Of course, settling this issue will involve a theoretical investigation into the possibility of rational practical reasoning, as the possibility of this faculty is so often being questioned in the 20th century (Weber, 1921). However, we follow Habermas' rebuttal of Webers skepticism in this respect (Habermas, 1981). In this paper we concentrate on a much smaller issue. We turned to the empirical world and simply studied the way in which contemporary competition law is organized. We investigated whether exceptions have been considered or actually have been made by the authorities, even if these authorities were strongly committed to installing competitive markets. Distinguishing our empirical question from the fundamental one is relevant. Even if practical reasoning is actually possible, our latter-day culture may very well still be under the spell of Weberian thinking. We assumed that if it is believed that the (judgements leading up to these) exceptions can be based on reasonable principles, then we have reason to qualify the thesis that we are confronted with an either/or decision, in the sense that at least in the perception of reasonable actors, these exceptions can be made. This conclusion is of course reinforced if these exceptions specifically concern CSR. We have limited our investigation to the recent Dutch situation (1997-2005).

\section{Some assumptions}

In order to understand the reasoning leading up to our research question and our choice for a study of the Dutch situation, three preliminary remarks have 
to be made. The first concerns the definition of CSR. In this paper we assume that CSR presupposes some discretion and that CSR is thus impossible on Neo-classical perfect markets. The fact that CSR presupposes some discretion follows from our definition of CSR as a moral obligation. A possible objection against this argument is to say that CSR and perfect markets may go hand in hand as long as all the CSR activities of a company are profitable. Actually, it is not uncommon to define CSR as a specific sort of profitable business activity (Husted and Salazar, 2006). However, we follow Scherer et al. (2006, pp. 515-517; see also Friedman, 1970) in their conclusion that at its core, CSR concerns an additional moral role of business that cannot be fully reduced to its economic role. We therefore maintain that CSR does imply some discretion and is thus not compatible with a perfect market.

The second remark concerns the nature of market competition and its relation to the law. Economists have a tendency to conceive of competition as a natural phenomenon (Commons, 1924) and thus are easily inclined to contrast a natural situation of perfect competition with an unnatural situation of interfering with this natural situation by means of law. Such thinking feeds either/or thinking. Now, perhaps it is true to say that some forms of competition are inherent in the natural world and grow spontaneously. All kinds of animals compete with one another. However, there is nothing spontaneous about the kind of competition that should reign on the free market - thus creating all kinds of beneficial consequences. Market competition is an artifact, created by institutions grounded in the law (Pigou, 1920, p. 128; see also: Engelen, 1995; Hodgson, 1988; Polanyi, 1944). Without strict laws, market actors would perhaps not fully give up all forms of competition but they would not only compete. They would hatch pacts with some competitors against others and/or with some other competitors against the public etc. They would probably also not restrict their means of competing to the ones beneficial to the good working of the market. The end result would probably look more like a war scene than a market place.

That market competition is an artificial situation construed by competition law, makes one understand the assumption of Jeurissen and van der Ven and embraced in this paper - that competition needs to be organized and that this organization does not necessarily have to take one and only one form. It also clarifies why allowing for exceptions with regard to competition may not necessarily be an either/or issue. Finally, it also illuminates why this paper concentrates on investigating competition law. It is therefore important to explicate that we assume that market competition is a construct, created by the state by means of the law. In fact it is a difficult process that requires permanent attention since if there is something natural about markets, it is not the businessman's strive to rule out a competitor but his strive to rule out competition itself. Society therefore not only stands in need of good laws but also in need of executive institutions that supervise market processes.

The third remark touches on our choice to focus the investigation on the Netherlands. Our basic reason is that during the period under investigation (1997-1995) the Netherlands in fact constitute an exemplary case as the Dutch were committed to both strengthen the competitiveness of the market and allow for exceptions on behalf of noneconomic values such as CSR. During the 1990s strong political forces within the Dutch government were out to change the old competition law. The Netherlands had always been a corporatist country that allowed for many kinds of inter-firm and corporatist cooperation (Couwenberg, 1953; Van Vliet, 1992). Due to scandals (such as the construction fraud), changing international market conditions and EU pressure the government came to believe that a new competition law was due $e^{5}$ and that this law had to be stringent and fully in line with EU regulation. However, it is also true that CSR is considered important in the Netherlands. And it is not just that consumers, citizens and NGO's find CSR important. Parliament and the government also have embraced CSR and have declared that they strive to promote CSR. ${ }^{6}$ We may thus expect politics to be sensitive to the argument that fierce competition may involve losses, such as obstructing the possibility of CSR and consequently that the Dutch context will preserve us from a doctrinal and categorical rejecting of any good argument to make an exception to the rule that inter-firm cooperation must be prohibited.

In the following four sections we will provide an overview of the case, starting with a brief history of 
the new competition law. Our analysis follows in section "Analysis of the case study and conclusion".

\section{Aims of competition regulation in the Netherlands}

The Dutch Competition Act (DCA) of 22 May 1997 is the main national law for the regulation of economic competition in the Netherlands. ${ }^{7}$ Regulation in the Netherlands is modelled closely after European regulation, and shares many similarities with regulation in a number of other EU member states. In addition to the DCA, another important instance of competition regulation that affects the Dutch market is European Union (EU) regulation. European competition regulation is enforced by the European Commission and based primarily on the EC Treaty of 1957, which established the predecessor of the EU. The main purpose of EU competition regulation is the creation of a common market (Scherer, 1994, pp. 34-35; SER, 2003, p. 25). In 1957 the EC Treaty required the adhering states to open their markets to one another. They did this by removing tariff barriers. However, an additional requirement was that monopolistic practices would cease. Otherwise certain markets would be de facto inaccessible to foreign competitors. Building and strengthening the common market remains the primary raison d'etre of the EU, which is fundamentally a political institution. Therefore, EU competition regulation goes beyond purely economic considerations.

Since 1 May 2004 all national competition authorities are empowered to apply the provisions of the EC Treaty. Also national courts may apply these provisions directly. ${ }^{8}$ The main focal points in the European Commission's competition policy are anti-trust policy, merger control, liberalization, and state aid. In the context of CSR, anti-trust policy and merger control are the more important themes because they refer directly to business activity. Antitrust regulation at the EU level consists of two main elements: the prohibition on anti-competitive agreements (EC Treaty article 81 ) and the prohibition on abusing a dominant market position (EC Treaty article 82). Merger control is aimed at preventing diminishing competition as a result of the merger of two or more enterprises.
The Dutch Competition Act has three main elements, which mirror the part of EU regulation that is aimed at enterprises: the prohibition on anticompetitive agreements (DCA article 6), the prohibition on abusing a dominant market position (DCA article 24.1), and merger control. To a very large extent these elements in Dutch law are either identical or complementary to EU regulation. ${ }^{9}$ DCA article 6 is copied directly from EC Treaty article 81. ${ }^{10}$ Moreover, in various articles the Dutch Competition Act refers explicitly to EU regulation. For the purpose of the present study it is important to note that Dutch law functions in close conjunction with EU regulation. Moreover, the contents of Dutch law - and the way in which it is enforced reflect to an important extent the main EU rules that apply to competition behaviour by enterprises in the Netherlands.

Before the Competition Act came into effect on 1 January 1998, competition regulation in the Netherlands had been far less stringent. In the mid-1990s Minister of Economic Affairs G.J. Weijers was responsible for the preparation of the proposed law and its submission to parliamentary approval. To explain to parliament, the need for the DCA, he pointed at the implications of the process of globalization. ${ }^{11}$ According to Weijers, the Dutch economy needed to become more competitive vis-à-vis the global economy. This could be achieved only if existing anti-competitive practices, which in effect shielded sections of the Dutch market from international competition, would be abolished. The law was adopted by parliament without major changes. The primary purpose of the DCA - as intended by its makers - therefore is to eliminate anti-competitive practices in order to make the Dutch economy more internationally competitive in the long term.

The Competition Act stipulates that its enforcement is the task of the Netherlands Competition Authority, known as NMa ('Nederlandse Mededingingsautoriteit'), which formally has this function since 1 January 1998. ${ }^{12}$ The NMa has the mandate to investigate instances of suspected breaches of the Competition Act. Companies found entering into agreements with competitors or abusing a dominant position with the aim of limiting competition are fined. The NMa can also prohibit mergers if they have a limiting effect on competition. In addition to enforcing the DCA, 
the NMa also has the task of enforcing articles 81 and 82 of the EC Treaty in the Netherlands, as well as implementing and supervising the Electricity Act (1998) and the Gas Act (2000). ${ }^{13}$ On 1 July 2005 , as a result of a modification of the DCA, the $\mathrm{NMa}$ became an autonomous government agency (ZBO, zelfstandig bestuursorgaan). ${ }^{14}$ This means that although the agency is funded by the Ministry of Economic Affairs, the minister is responsible only for appointing the NMa's board of directors. ${ }^{15}$

With regard to inter-firm cooperation, the DCA stipulates that 'agreements between undertakings, decisions by associations of undertakings and concerted practices of undertakings, which have as their objective or effect the prevention, restriction or distortion of competition on the Dutch market, or part thereof, are prohibited' (DCA 6.1). However, the prohibition does not apply to agreements, decisions or concerted practices that 'contribute to improving production or distribution, or promoting technical or economic progress, while allowing consumers a fair share of the resulting benefit'. In order to be allowed such cooperation, it must not impose on the undertaking concerned restrictions which are not indispensable to the attainment of these objectives, or afford such undertakings the possibility of eliminating competition in respect of a substantial part of the products and services in question' (DCA 6.3). The prohibition also does not apply to cooperation involving a low number of firms and a low combined size in terms of turnover (DCA 7.1).

In principle, all forms of inter-firm cooperation that noticeably affect competition are illegal. This applies not just to formal agreements, but also to 'concerted' behaviour that results in limiting competition. Exemptions are allowed for cooperation leading to technical or economic progress, but never if this burdens consumers or threatens competition. The Competition Act aims at removing existing and precluding potential restrictions to competition.

\section{CSR as a potential ground for exception}

The DCA does not mention the term 'corporate social responsibility' or a closely related term. In 1997, when Dutch parliament discussed the proposed Competition Act, demands were voiced by some Members that social, cultural, and environmental interests ought to be taken into account when enforcing the DCA. Minister of Economic Affairs Weijers felt that such so-called 'noneconomic interests' should be secured through separate laws. Nonetheless, he promised parliament that he and his successors would take action if cultural, social, environmental, housing, or healthcare interests are at stake. In case it happened, the minister would instruct the NMa, at the general level, to change its policy. ${ }^{16}$ In 2001 and 2002 this issue was discussed again in parliament when Weijers' successor, Minister A. Jorritsma, proposed to change the Competition Act in order to give the NMa more autonomy. ${ }^{17}$ Two aspects in particular were highlighted in this discussion. ${ }^{18}$

First, there were concerns about the lack of political supervision regarding the relationship between competition law enforcement and general public interests. The Labour Party (PvdA) stated that it was not yet sufficiently clear how competition regulation related to general public interests such as environmental or social themes, and that it therefore was too early to remove direct political supervision. A broad range of parties - Labour, the Green-Left Alliance (Groen Links), the Christian-Democratic Appeal (CDA), and the Christian Union (Christen Unie) - worried that a more autonomous NMa would in practice come to decide on how competition and societal aims are to be balanced against each other. The CDA explicitly used the term CSR (maatschappelijk ondernemerschap) in this context. For the time being, all wanted government to stay in charge of deciding on cultural, environmental, and social issues in relation to competition.

The minister refuted these concerns by arguing that NMa's mandate is sufficiently clear. Thus, minister Jorritsma maintained that there is no need whatsoever for the minister of Economic Affairs to retain the right to intervene in decision-making on individual cases. ${ }^{19}$ The Competition Act is 'an economic law with economic aims'. The NMa can carry out what is stipulated in this law, and therefore has to keep to economic considerations. Consistent with this line of reasoning the minister further argued that although the DCA allows exemptions in relation to non-economic aims, exemption can never be granted merely on noneconomic grounds. Still, Minister Jorritsma also 
pointed out in parliament that she, as minister, would still retain the right to issue general instructions to the NMa on policy rules for deciding on interests other than economic interests.

Second, there were concerns that the NMa would overemphasize the importance of competition. The Labour Party feared that an increase in the NMa's discretion could turn competition into an absolute, while it should more properly be seen as a principle that is not necessarily always the most desirable in societal terms. The Green-Left MPs pointed out the danger that the NMa might avoid making decisions on non-competition themes altogether. Consequentially other public interests than competition simply would not be taken into account.

The minister rebutted that whether or not certain issues are to be exempted from competition regulation is a matter to be settled through legislation. Thus Jorritsma repeated her predecessor Weijers' position that limitations to competition regulation are external to the Competition Act. These matters should be addressed in separate laws. In a newspaper article published in 2001 the minister argued that CSR is full well possible under maximized competition. As she saw it, some companies tend to use corporate social responsibility as an excuse to establish trusts. She therefore made it clear that the $\mathrm{NMa}$ would maintain its restrictions on inter-firm cooperation, and that she believed that this would leave ample room for CSR. ${ }^{20}$

In 2002, independent legal experts evaluated the functioning of the DCA. They concluded that it is not desirable that attempts would be made to establish more clearly how much room there is for non-economic criteria under the Competition Act. They feared that this would produce a flood of arguments that would be uncontrollable by the $\mathrm{NMa}^{21}$ They, too, came to the conclusion that, if necessary, non-economic interests should be protected by new legislation that would stipulate in which instances anti-trust prohibitions are not applicable.

The Social and Economic Council of the Netherlands (SER), the main advisory body to government and parliament on economic and social issue, has noted that competition law tends to favour direct government regulation of social and environmental issues over 'self-regulation', or voluntary (CSR) initiatives by business (SER, 2002, p. 46). The SER advised the Dutch government to insist on a revision of the criteria in EC Treaty article 81.3, which stipulate the reasons for exemption to the prohibition on inter-firm cooperation (SER, 2003, p. 57). The SER believes that non-economic criteria such as cultural and environmental interests should be taken into account by the NMa. ${ }^{22}$ The government chose not to follow or to respond to this advice. ${ }^{23}$

From 1998 until mid-2005, when the NMa gained its status of autonomous agency, it had been possible for the minister to intervene in individual NMa decisions if these conflicted with the broader public interest. In theory, this might have been the case if it became apparent that the work of the NMa interfered with the promotion of CSR. The Ministry of Economic Affairs is also the main coordinating institution for policy-making on CSR in the Netherlands. However, no intervention has ever been made by the minister, regardless of the reason.

\section{The discretion of the NMA}

After the new competition law was issued, the role of the NMa - as the upholder of that specific law became more important, especially so since the NMa has some discretion with regard to applying the law to specific cases. As such the NMa declared its mission to be 'to make markets work'. It thus lined up more with the DCA the main purpose of which is enhancing the competitiveness of the Dutch economy, than with the EU regulation's aim to create a common market and thus further European integration. A well-functioning market is defined as following by the NMa: 'Wherever markets operate properly, undertakings will compete for the favour of the consumer. Such market operations have proved to be the most beneficial to stimulating innovation and efficiency. This contributes to general prosperity. ${ }^{24}$ To the NMa the ultimate criterion to evaluate competition is whether the consumer is disadvantaged. ${ }^{25}$ To determine what is in the interest of consumers, the NMa looks at the quality and prices of products ${ }^{26}$ : 'Increased competition results in novel and highquality products with a more favourable price/ cost-ratio'. ${ }^{27}$ Thus, while regulation itself is aimed at maximizing the intensity of competition in the Dutch market, the NMa's touchstone for this is 
consumer welfare in terms of price and quality of available products.

The main publication in which the NMa explains how it assesses various types of inter-firm cooperation is the 'Richtsnoeren Samenwerking Ondernemingen' (Guidelines on cooperation between undertakings, hereafter 'Guidelines'). ${ }^{28}$ Also with specific regard to cooperation aimed at CSR, this is the main guideline provided by the $\mathrm{NMa}^{29}$ The Guidelines make it clear that whether a form of cooperation is prohibited depends on a large number of variables, such as firm size, firm type, and the nature of the agreement. It therefore is difficult to decide whether a particular instance of cooperation is prohibited without a detailed investigation and without consulting the NMa on a specific case.

Cooperation between companies aimed at CSR in supply chains takes two basic forms. One is horizontal cooperation, between competitors. The other is vertical cooperation, between a supplier and a client firm. In order to get a full picture of the NMa's policies, we have to consider both types. Regarding horizontal cooperation, the main principle of the NMa is that all agreements between competitors on price, market sharing, or selling conditions that discriminate between buyers are by definition aimed at limiting competition, and therefore prohibited (Guidelines, pp. 10-11). The NMa allows the sharing of information as long as this does not result in gaining insights into the competitive strategy of competitors (Guidelines, p. 17). Cooperation must not reduce market participants' uncertainty about each other's behaviour. Important factors in this context are the involvement of information on prices, production, market output, and customers; the level of detail; the frequency of information exchange; and whether access to information is restricted (Guidelines, p. 18). Cooperation between competitors aimed at creating a countervailing power to dominant customers or suppliers must be considered prohibited (e.g., Bruins et al., 2002, p. 19).

Vertical cooperation is an even more complicated matter. The European Commission's regulation on block exemptions for vertical agreements applies to the Netherlands, and is executed as such by the NMa. The European Commission has published a set of guidelines to explain the functioning of this regulation. ${ }^{30}$ Vertical agreements are generally allowed if the firms involved have a market share less than $30 \%$, and when certain conditions are taken into account. The 30\% market share applies to the supplier role of the participating companies. Vertical agreements are not allowed to contain 'severely' anti-competitive restrictions such as minimum or fixed resale prices, or certain types of territorial protection. $^{31}$

Let us take a closer look at which pricing restrictions are not allowed. Commission Regulation No. 2790/1999 of 22 December 1999 (EC) ${ }^{32}$ states in article 4(a) that the block exemption to vertical agreements does not apply if these are aimed at 'the restriction of the buyer's ability to determine its sale price, without prejudice to the possibility of the supplier's imposing a maximum sale price or recommending a maximum sale price, provided that they do not amount to a fixed or minimum sale price as a result of pressure from, or incentives offered by, any of the parties'. In other words, an agreement between a supplier firm and a buyer firm may not result in a fixed or minimum price for the buyer firm's customers. Vertical agreements that result in a higher price for the end consumer thus are not exempt from the overall anti-cartel prohibition.

Vertical inter-firm cooperation for CSR often involve product certificates or codes of conduct. Regarding agreements that involve product certificates it depends on specific conditions whether these are allowed. In general, vertical agreements are not likely to be exempt from anti-cartel prohibition if they result in higher consumer prices or barriers to new market entrants. ${ }^{33}$ This means that in principle vertical agreements involving CSR certification are possible, but only within strict limits. With regard to codes of conduct, no stipulations are included in the EC block exemption for vertical agreements. However, the NMa guidelines cover this topic at the general level, pertaining to any kind of inter-firm cooperation. Codes of conduct are not allowed if they restrict competition or if they set minimum sales prices. ${ }^{34}$ Like certification, therefore, they are possible under certain strict conditions.

Vertical agreements involving certification or codes of conduct are generally possible, but those involving prices often are not. Supply chain initiatives that involve establishing minimum prices to cover the costs for socially and environmentally sustainable production can be a problem, depending 
on the market share involved. But the real bottleneck is horizontal cooperation between companies. If aimed at decreasing competitive pressure this is not allowed by competition regulation.

\section{The NMa and CSR}

Unfortunately, it was not possible in this study to establish with full certainty in how many instances CSR-aimed cooperation between companies was prohibited by the NMa. Cases in which the firms involved explicitly used the term CSR (i.e., its Dutch equivalent $M V O$ ) were not found among the decisions publicly accessible on the NMa's website. Nor could an instance of cooperation aimed at eliminating negative social or environmental effects otherwise be found that was prohibited by the NMa. Consulting a number of experts likewise produced no information on specific instances where actions of the NMa interfered with CSR initiatives. ${ }^{35}$

However, some information on the CSR-policy of the NMA could be detected. The NMa made a few comments on CSR in general and there are a few cases that are of interest for our research. The NMa's official policy regarding inter-firm cooperation with the purpose of CSR is that the agency views such initiatives positively, but that they do need to comply with the DCA ${ }^{36}$ In its annual report for 1999, the NMa explicitly stated that - within the limits posed by the DCA - the agency may take protection of the natural environment into account. ${ }^{37}$ It has done so in at least four decisions on specific cases. ${ }^{38}$ However, the NMa has not indicated whether it will take non-economic interests other than the environment into consideration. ${ }^{39}$

Even if there are no cases that specifically deal with CSR, there are some that are of interest for our research. First, there are the before-mentioned cases related to the protection of the natural environment. We will take a closer look at one example that is typical of these four cases involving the environment, the so-called Stibat case. Stibat is a foundation created by Dutch manufacturers and importers of batteries, intended to carry out their legal obligation to take responsibility for the collection and recycling of used batteries. ${ }^{40}$ In 1998 the NMa decided that Stibat is exempt from the DCA with regard to the joint collection and removal of batteries, including defining the extra price per battery to be paid by the participating manufacturers and importers. ${ }^{41}$ The NMa reached this decision because the collection system served both environmental and economic purposes. ${ }^{42}$ However, exemption was not granted with regard to the Stibat practice of obliging the participating companies to charge to their customers (wholesale companies) the full amount of the costs for battery removal. The NMa requires participating companies to retain the option of charging less than the full costs to customers in order to become more competitive. ${ }^{43}$ This case suggests that the NMa allows a certain degree of cooperation aimed at environmental purposes, even if it involves prices and if environmental damage was already precluded by the existence of a specific law. The NMa allowed this under the condition that economic purposes are likewise served and that competition is not affected. A price raise that precludes the possibility of increased competition was not allowed in this instance.

Next to the environmental cases there are two cases partly related to CSR, that are of interest for our purposes. One of these cases is the so-called 'milk dime' case. This case involved a price agreement intended to support producers. In 2001 major Dutch supermarket chains and milk processing firms decided to raise the consumer price by 10 cents in order to support Dutch farmers, who were in economic difficulty because of an outbreak of foot-andmouth disease. However, the extra funds would not be distributed to the farmers but to the milk processing firms, which are cooperative enterprises representing the farmers. The NMa prohibited this common 'solidarity price', stating that it did not object to companies supporting their supplier farmers, but to the fact that consumers are being forced to do the same. The NMa demanded that the interfirm price agreement must be ended so that competition would be restored. ${ }^{44}$

The next case concerns a prohibition in 2003 by the NMa on inter-firm agreements in the shrimp fishing industry was claimed by a Dutch member of the European Parliament (A.J. Maat, CDA) in a newspaper interview to be a case of anti-CSR interference by the NMa. ${ }^{45}$ The issue at stake, according to Maat, was that fisheries and other firms jointly decided to set fishing quotas in order to protect fish stocks. The aim of the agreement was thus said to be an example of sustainable business. 
However, according to the NMa the companies involved were unable to substantiate that their agreement was indeed aimed at preserving fish stocks. ${ }^{46}$ The NMa also noted that the type of shrimps involved are not in danger of disappearing, as was evidenced by current EU policy, and that the setting of fishing quotas was a matter for the EU or its member states.

What can the absence of NMa decisions involving unambiguous examples of CSR tell us? The NMa is unable to investigate all possible breaches of the DCA that occur in the Netherlands. The agency must decide how it deploys its resources, and is free to decide whether to investigate a specific instance. ${ }^{47}$ In principle, the competition authority supervises all market sectors, with a special focus on markets with a high degree of concentration and on shrinking markets. ${ }^{48}$ This suggests that CSR is not a factor in the NMa's selection process with regard to its own investigations. The fact that there have been few or perhaps no confrontations between the NMa and CSR initiatives suggests the possibility that CSR is a marginal phenomenon in the Netherlands (at least in fiercely competitive markets).

This could yet be related to the DCA. Its existence might deter firms from entering into cooperative agreements, or even preliminary contacts. ${ }^{49}$ Since CSR-aimed cooperation is not a priori either allowed or prohibited, but subjected to a complicated set of conditions, the companies face the risk that they may inadvertently breach the law. Addressing this risk involves legal expenses that could make the whole scheme unattractive, if possible public relations risks are considered to be less threatening. An evaluation of the DCA found that many firms have taken precautionary actions to avoid being fined by the NMa. ${ }^{50}$ According to Millstein and Katsh (1981, p. 50), 'even where activities present borderline questions [where it is difficult to say whether they are prohibited] corporations in many cases will tend to choose those commercial strategies presenting the fewest anti-trust risks consistent with commercial objectives involved'. Bruins et al. (2002, p. 23) mentions that sometimes industry associations find that the limitations on inter-firm cooperation obstruct environmental purposes. It is also conceivable that firms use the existence of the DCA as a pretext for not heading the call of NGOs to take certain CSR initiatives. A Dutch NGO, the Netherlands Society for Nature and Environment (Stichting Natuur en Milieu), claims that it learned from some of its business contacts in the food sector that these are deterred from inter-firm agreements for CSR that involve price setting (SNM, 2003, annex 2).

\section{Analysis of the case study and conclusion}

The aim of this case study on recent Dutch competition law has been to contribute to the issue whether a well-organized market necessarily has to be a perfect market in the Neo-classical sense. It was inferred that well-organized markets do not necessarily have to be perfect markets if reasonable and specific principles can be formulated that can allow for exceptions. This possibility depends on the availability of objective - or inter-subjective criteria, i.e., practical reason as such. But it also depends on the conviction of concrete reasonable beings that these principles exist. The case study provides us with the opportunity to say something about the latter. Two questions have to be distinguished in this regard: (1) do these concrete humans anticipate the possibility of formulating these principles at all? and (2) do they anticipate this possibility within the scope of CSR? In order to get a clear sight these questions must be answered twice: once in relation to the process of law making and the law itself (the framework level) and once in relation to the discretion of the NMa.

If we take the first question at framework level we can observe that neither parliament nor the government foresees any problems here. Both accept the proposition that at least some reasonable principles can be formulated that allow for the possibility of making reasonable exceptions. After all, parliament tries to convince the government that the law must somehow allow for exceptions with regard to the environment or social values. The government does not accept this argument. But it does allow for exceptions when these 'contribute to improving production or distribution, or promoting technical or economic progress, while allowing consumers a fair share of the resulting benefit'. If we answer the first question at the level of the NMa, we have to come to the same conclusion. Again, the NMa does not oppose to the idea of exceptions to the 
inter-firm cooperation as such. It allows for all kinds of exceptions and uses the proposition that interfirm cooperation must be in the interest of the consumer.

If we take a look at the second question at framework level, we must conclude that there has been some tension between parliament and government. Parliament does believe that reasonable exceptions can be made for CSR. According to parliament it is possible to organize a well-organized market and allow for inter-firm cooperation geared at fostering CSR. (Otherwise it would not have called for this exception.) The government did not accept the proposition. It argued that it is unwise to infect the competition law with all kinds of noneconomic concerns. Parliament therefore held it against government that it made economic goals into an absolute. This reproach is not completely justified. The government did not turn against noneconomic values. It turned against a particular way of achieving these values, i.e., it turned against a particular way of organizing the market. After all, according to the Dutch government these goals had to be achieved by making separate laws.

Still, in the context of this paper it is somewhat unfortunate that the government mainly opposed parliament by pointing out an alternative way to realize non-economic values. As a consequence, it did not explicate why exactly it stringently opposed allowing for exceptions to achieve non-economic goals. Was its opposition prudently motivated, in the sense that it believed that it is more accurate or proper to pursue non-economic goals by means of separate laws? Or was its opposition fed by the fundamental fear of subjectivism, as this was endorsed by the 'independent legal experts'? We cannot be sure. This is particularly unfortunate because many proponents of CSR (see for example Scherer et al., 2006) justify the necessity of CSR by claiming that this other route - realizing non-economic values by means of separate laws - is impassible. CSR is important exactly because of the 'limits of law' (Dubbink, 2003; Scherer et al., 2006). It can thus be stated that the issue how these other values can be realized has not been sufficiently addressed in the Dutch discussion. Consequently, the question why the government objected to allowing for exceptions to the principle that inter-firm cooperation on behalf of CSR has also not been sufficiently addressed. The government used an escape route that allowed it to ignore the issue. Consequently, we now are not able to determine whether the refusal to allow for exception was grounded in some partisan or political motive or whether it was grounded in the belief that no relevant distinction can be made between exceptions on behalf of economic reasons and exceptions on behalf of CSR.

Looking at the second question at the level of the $\mathrm{NMa}$, we are again confronted with tension, this time a double one. The first tension concerns the fact that the NMa on the one hand states that it is well disposed to CSR. On the other hand however, the NMa explicates that it will not allow for exceptions, exclusively grounded in fostering CSR. There has to be some benefit for the consumer as well. However, since the NMa has not thoroughly explicated its views on CSR, we do not know why the NMa does not want to make this exception. Possibly, the NMa holds that making exceptions on behalf of CSR will lure the organization into subjectivism. It might also be the case that the NMa thinks that making this type of exception is unnecessary, given alternative ways to realize the values behind CSR.

The second tension concerns a difference between the NMa's principle that it will not consider CSR cause for exception and its actual reasoning in some specific cases. Since the actual outcome of the milk dime case and the shrimp case seems to obstruct CSR and since the NMa only conditionally went along with the Stibat case, we might be inclined to conclude that the NMa in fact poses an important obstruction to CSR. However, if we focus on the NMa's reasoning and not on its conclusion in the milk dime case and the shrimp case, then we perhaps should qualify that conclusion. In fact, the NMa did not simply reject these exceptions because they violated the principle that any inter-firm cooperation must also benefit the consumer. In both cases the NMa went much further in its reasoning. In the milk dime case it questioned whether the initiative had anything to do with CSR, which indeed is a good question to ask. The milk dime case seems to be an exemplary case of one group spending another group's money. Thus, there is much to say in favour of the NMa conclusion that this has little to do with CSR. Again, interesting about the shrimp case is that the NMa does not simply dismiss the initiative because it goes against the consumer's interest. 
Instead it tries to give a substantive argument showing that the arguments of the industry were not solid. The concerned shrimps were not in danger of depletion and the measures taken by the industry were not geared to preserve the stock. Thus in both cases the NMa did come to a considered judgement that some might want to redress but in which noneconomic values (nature, solidarity) seemed to have gained more than just an additional value.

Before coming to a conclusion, let us look at the case from a different angle. The new DCA and the policy of the NMa have sometimes caused commentators to voice their concern for the possibility of CSR. It is not uncommon to suggest that CSR will be impossible under the new institutional arrangement, since no form of inter-firm cooperation will be allowed. Thus, L. De Waal, then chairman of an important Dutch Labor Union, stated that the new arrangement would make it harder for companies to cooperate with each other to achieve common CSR aims. ${ }^{51}$ Again, in a recent article in the Financial Times Europe it was noted that: 'Companies that want to foster responsible business practices may be surprised to learn that they must also be careful not to breach the law. Certainly, when it comes to one recent trend - for companies in an industry to group together to address labour and environmental conditions - they must pay attention to how such collaborations may be viewed by anti-trust regulators' ${ }^{52}$ If we look at the few encounters between CSR and the NMa we might at first sight be inclined to interpret the evolving experience as proof of that concern.

However, in our case study we have looked at the issue from another angle. We have taken up the issue whether well-organized markets necessarily have to be perfect markets in the Neo-classical sense or whether other types of markets might also be considered well organized, in the sense that there is room for reasonable exceptions to the rule that inter-firm cooperation ought to be rejected, on the basis of reasonable principles. Looking at the Dutch situation we can conclude that all actors involved always see room for some exceptions based on reasonable principles. Some actors, such as (parts of the) Dutch parliament also explicitly maintain that CSR gives cause for reasonable exemption. Other actors, such as the government and the NMa seem to have some fear that allowing for CSR will throw us in the swamp of subjectivism. However, the principle discussion on this subject has not been pursued. The government avoids touching on the issue by claiming that other means are available to realize non-economic values. What is more, the NMa seems to consider cases of CSR more thoroughly then it must, based on its principle that CSR does not have independent meaning. We may therefore conclude that many actors in the Dutch case do not conceive of allowing for exceptions as an either/or choice. They believe reasonable principles can be formulated and reasonable judgements can be made to allow for exceptions. At least in that regard well organized but not perfect markets are possible.

\section{Notes}

1 Original quote by H.R. Bowen published in 1953.

2 Even if a well-organized society can only be realized if the market is part of an institutional arrangement in which other basic institutions - such as the state also have their place.

3 This is not to say that CSR always presupposes inter-firm cooperation. On markets not sufficiently competitive, corporations may gain such a degree of discretion that they can act socially responsible without the need to coordinate their actions with their direct competitors.

4 Actually, Kimman speakes of 'self-regulation' but in the context it is clear that he also includes CSR in this somewhat broader concept.

5 Weijers, J.J. 'Nieuwe regels omtrent de economische mededinging (Mededingingswet), memorie van toelichting', Tweede Kamer der Staten Generaal, meetings 1995-1996, 24,707, No. 3, http://www.parlando. sdu.nl/cgi/login/anonymous.

6 http://www.ez.nl/dsc?c=getobject\&s=obj\&objectid $=$ 150593\&!dsname=EZInternet\&isapidir=/gvisapi/.

7 For the English version of the Dutch Competition Act see http://www.nmanet.nl/Images/14_26063_ tcm16-24409.pdf (24 July 2006).

8 http://www.ec.europa.eu/comm/competition/anti trust/overview/ (7 Aug. 2006).

$9 \operatorname{SER}$ (2003, pp. 26-29).

10 EC Treaty art. 81 has never been modified since 1957, and therefore DCA art. 6 closely follow the text of the original EC Treaty. This applies also to the identification of the two preconditions to exemptions, technical and economic progress: SER (2003, p. 57). 
11 J.J. Weijers, 'Nieuwe regels omtrent de economische mededinging (Mededingingswet), memorie van toelichting', Second Chamber, meetings 1995-1996, 24,707, No. 3, http://www.parlando.sdu.nl/cgi/login/ anonymous. Also "Wet maakt einde aan "kartelparadijs", NRC Handelsblad (4 July 1995); and 'Nieuwe mededingingswet Weijers verbiedt prijsafspraken tussen concurrenten', Trouw (3 May 1996).

12 http://www.nmanet.nl/nederlands/home/Wet_en_ regelgeving/Mededingingswet/Index.asp (12 July 2006).

13 A further number of sector-specific acts give the NMa a mandate for competition enforcement: the Railway Act, the Aviation Act and the Passenger Transport Act (2000). http://www.nmanet.nl/engels/home/ About_the_NMa/Index.asp (24 July 2006).

$14 \mathrm{http} / / / \mathrm{www} \cdot \operatorname{minez} \cdot \mathrm{nl} / \mathrm{dsc}$ ? $\mathrm{c}=$ getobject\&s $=$ obj\&!ses sionid=1sUhCt3Q4eGBJh@OuGEX@hWdpz8XH5!b 8BG1jif5 WxRDe8Ga59bo5Wz8ZWno7p!8\&objectid= $34404 \&$ !dsname $=E Z I n t e r n e t \& s i t e n a m e=E Z-n l \& l o g g e t$ object=true\&isapidir=/gvisapi/ (12 July 2006).

15 http://www.regering.nl/trefwoordenregister/42_ 7837.jsp (12 July 2006). Details on the relationship between the ministry and the NMa are given in two official documents 'Relatiestatuut' http://www.nmanet. $\mathrm{nl} /$ Images/Relatiestatuut\%20NMa\%20-\%20EZ\%20 finaal_tcm16-83592.pdf and 'Uitwisseling gegevens' http://www.nmanet.nl/Images/Ministeriele\%20regeling \%20uitwisseling\%20NMa-EZ_tcm16-83593.pdf (28 July 2006).

16 'Bij mededinging tellen ook andere belangen dan economische mee', Trouw (12 March 1997), p. 4.

17 Taco Mulder, 'Jorritsma beloont de NMa met onafhankelijkheid', Het Financieele Dagblad (21 March 2001); 'Jorritsma wacht spannend debat over zelfstandiger positie van NMa', Het Financieele Dagblad (28 Jan. 2002), p. 5.

18 Questions by the Parliamentary Committee on Economic Affairs and reply by Minister of Economic Affairs A. Jorritsma, Second Chamber, 2000-2001, 27,639, Nos. 4 and 5, respectively, http://www. parlando.sdu.nl/cgi/login/anonymous (5 Aug. 2006).

19 As mentioned before, in the end no minister ever interfered in the NMa's enforcement of the DCA for what reason whatsoever. When the NMa became an autonomous agency in 2005, the minister of Economic Affairs lost the right and duty to interfere in individual NMa decisions that involve non-economic interests.

20 Rijk Timmer, 'Jorritsma vindt kritiek op NMa onzin', Financieele Dagblad (21 June 2001). What exactly the minister meant by 'ample room' was not explained in this source.

21 P.J. Plug, 'Syntheserapport evaluatie Mededingingswet' (30 May 2002), http://www.nmanet.nl/Images/ 11_20154_tcm16-19925.pdf (5 Aug. 2006).
22 For an abstract in English of this advice see http:// www.ser.nl/default.asp?desc $=2003 \_06$.

$23 \mathrm{http} / / / \mathrm{www} \cdot \mathrm{ser} \cdot \mathrm{nl} /$ publicaties/default.asp?desc $=\mathrm{b} 21$ 635 (7 Aug. 2006).

24 NMa, Annual Report NMa 2005 (The Hague: NMa, 2006), pp. 4-5.

25 P. Kalbfleisch, 'Coöperatie en mededinging' (address at a meeting of cooperative enterprises, 17 Nov. 2005), p. 13, http://www.nmanet.nl/images/051118\%20cooperaties \%20en\%20mededinging\%20def\%20_2_tcm16-81831.pdf (2 Aug. 2006).

26 'A.W. Kist, directeur-generaal Mededingingsautoriteit', Trouw (26 Nov. 1997), p. 7.

$27 \mathrm{NMa}$, Annual Report NMa 2005 (The Hague: NMa, 2006), p. 5.

$28 \mathrm{NMa}$, 'Richtsnoeren samenwerking ondernemingen' (The Hague: NMa, 2005).

29 P. Kalbfleisch, 'Coöperatie en mededinging' (address at a meeting of cooperative enterprises, 17 Nov. 2005), p. 13, http://www.nmanet.nl/images/051118\% 20 cooperaties $\% 20$ en $\% 20$ mededinging $\% 20 \mathrm{def} \% 20 \_2 \_$tcm 16-81831.pdf (2 Aug. 2006).

30 European Commission, 'Guidelines on Vertical Restraints' (Brussels: EC, 2000), http://www.eur-lex.europa. eu/LexUriServ/site/en/oj/2000/c_291/c_29120001013 en00010044.pdf (28 July 2006).

31 http://www.eur-lex.europa.eu/LexUriServ/site/en/ oj/1999/1_336/1_33619991229en00210025.pdf (28 July 2006).

32 http://www.eur-lex.europa.eu/LexUriServ/site/en/ oj/1999/1_336/1_33619991229en00210025.pdf (28 July 2006).

$33 \mathrm{NMa}$, 'Beleid inzake verticale overeenkomsten' (The Hague: NMa, 2003), p. 13.

34 NMa, 'Richtsnoeren samenwerking ondernemingen' (The Hague: NMa, 2005), p. 27.

35 The experts were asked whether they know of any instances of CSR initiatives conflicting with the NMa's enforcement of Dutch Competition Law. Persons consulted: M. Jacobs (Ministry of Economic Affairs) 13 July 2006, M. van Kordelaar (NMa) 29 Aug. 2006, B. Rutgers van der Loeff (Confederation of Netherlands Industry and Employers VNO-NCW) 12 Oct. 2006, S. van Bennekom (Oxfam Novib) 20 July 2006, J. Oldenziel (Centre for Research on Multinational Corporations SOMO) 25 July 2006, and L. Simons (Utz Kapeh) 19 July 2006.

36 P. Kalbfleisch, 'Coöperatie en mededinging' (address at a meeting of cooperative enterprises, 17 Nov. 2005), p. 11, http://www.nmanet.nl/images/051118\% 20cooperaties $\% 20$ en $\% 20$ mededinging\%20def $\% 20 \_2 \_t c m$ 16-81831.pdf (2 Aug. 2006). 
37 NMa, Jaarverslag NMa 1999 (The Hague; NMa 2000), p. 25.

38 Besides the Stibat decision these are decision case 12/FKS (23 July 1999), decision case 492/VBN (9 July 1999), and decision case 2495 (18 Apr. 2001).

39 P.J. Slot et al., 'Eindrapport evaluatie Mededingingswet: Juridisch deelonderzoek', p.21, http://www.nmanet. nl/Images/11_20155_tcm16-19926.pdf (5 Aug. 2006).

40 http://www.stibat.nl/nl/tabalgemeen/overstibat.asp? m=11 (3 Aug. 2006).

41 'Batterijenrecycling mag collectief, Financieel Dagblad (29 Dec. 1998), p. 15.

42 'NMa geeft ontheffing voor inzameling batterijen', Financieel Dagblad (29 Dec. 1998), p. 4.

43 Decision 31 May 1999 regarding case 58/Stibat, art. 47 and 48, http://www.nmanet.nl/Images/bbb00519905_tcm16-45608.pdf (3 Aug. 2006).

44 'Pak melk moet weer dubbeltje goedkoper', Trouw (13 Apr. 2001), p. 3.

45 'Wildwesttaferelen na ontbinding garnalenkartel', Het Financieele Dagblad (6 May 2003).

46 http://www.nmanet.nl/Images/2269BLD_tcm1647110.pdf (1 Nov. 2006).

47 Decision 3607-60 Consumentenbond v. shampoo manufacturers (17 Aug. 2004), p. 3, http://www.nmanet. nl/Images/3607bbma_tcm16-47705.pdf (3 Aug. 2006).

48 P. Kalbfleisch, 'Coöperatie en mededinging' (address at a meeting of cooperative enterprises, 17 Nov. 2005), p. 12, http://www.nmanet.nl/images/051118\% 20cooperaties $\% 20$ en $\% 20$ mededinging $\% 20$ def $\% 20 \_2$ _tcm 16-81831.pdf (2 Aug. 2006).

49 Discussed at the international level: Sarah Murray, 'Responsibility allies heed antitrust traps', Financial Times Europe (5 January 2006).

50 Minister of Economic Affairs to Second Chamber 31 May 2002, http://www.nmanet.nl/Images/ 11_20153_tcm16-19924.pdf (4 Aug. 2006).

51 L. de Waal (leader, Dutch trade union FNV), 'MVO: Mode of must?' (Speech, The Hague, 24 Apr. 2002), http://www.fnv.nl/pers/renderer.do/menuId/ 8893/clearState/true/sf/8893/returnPage/8893/itemId/ 1274/pageId/40144/instanceId/8896/ (4 Aug. 2006); SNM (2003, 2004).

52 Sarah Murray, 'Responsibility allies heed antitrust traps', Financial Times Europe (5 January 2006).

\section{Acknowledgements}

The authors thank Sander van Bennekom, Mandy Bosma, Gemma Crijns, Nadja Duykers, Mario Jacobs,
Ronald Jeurissen, Johan Graafland, Edgar Karssing, Mark van Kordelaar, Joris Oldenziel, Bram Rutgers van der Loeff, Lucas Simons, Diederik Timmer, and Elsabé Willeboordse for their help. This study was financed by the Netherlands Organisation for Scientific Research NWO, as a part of the project 'markets, morality and politics: the political implications of corporate social responsibility'.

\section{References}

Baumol, W. J.: 1975, 'Business Responsibility and Economic Behavior', in M. Anshen (ed.), Managing the Socially Responsible Corporation (MacMillan, New York), pp. 59-74.

Baumol, W. J. and S. J. Batey Blackman: 1991, Perfect Markets and Easy Virtue: Business Ethics and the Invisible Hand (Basil Blackwell, Oxford).

Bruins, A, et al.: 2002, Samenwerking in het $M K B$ en de Mededingingswet (EIM, Zoetermeer).

Carroll, A. B.: 1999, 'Corporate Social Responsibility: Evolution of a Definitional Construct', Business and Society 38(3), 268-295.

Commons, J. R.: 1924, Legal Foundations of Capitalism (MacMillan, New York).

Cottrill, M. T.: 1990, 'Corporate Social Responsibility and the Marketplace', Journal of Business Ethics 9, 723729.

Couwenberg, S. W.: 1953, Het Particuliere Stelsel. De Behartiging van Publieke Belangen door Particuliere Lichamen (Samsom, Alphen aan den Rijn).

De George, R. T.: 1999, Business Ethics, 5th Edition (Upper Saddle River).

Dubbink, W.: 2003, Assisting the Invisible Hand. Contested Relations Between Market, State and Civil Society. Issues in Business Ethics Series (Kluwer, Dordrecht).

Engelen, E.: 1995, De Mythe van de Markt. Waarheid en Lengen in de Economie (Amsterdam).

Friedman, M.: 1970, 'The Social Responsibility of Business is to Increase Its Profits', The New York Times, September 13, p. 33.

Habermas, J.: 1981, Theorie des kommunikativen Handelns. Two Volumes (Suhrkamp, Frankfurt am Main).

Hayek, F. A.: 1980, Individualism and Economic Order (The University of Chicago Press/Midway, Chicago).

Hodgson, G. M.: 1988, Economics and Institutions. A Manifesto for a Modern Institutional Economics (Polity Press, Cambridge).

Husted, B. W. and J. Salazar: 2006, 'Taking Friedman Seriously: Maximizing Profits and Social Perfor- 
mance', Journal for Management Studies XXXXIII, 75-91.

Jeurissen, R. and B. van der Ven: 2005, 'Competing Responsibly', Business Ethics Quarterly 15(2), 299-317.

Jeurissen, R. and B. van der Ven: 2006, 'Maatschappelijk Verantwoord Ondernemen en Strategie', in R. Jeurissen (ed.), Bedrijfsethiek een Goede Zaak, 6th Edition (Assen).

Kimman, E.: 2006, Verkaveling van de Moraal: Inleiding Bedriffsethiek, 3rd Edition (Amsterdam).

Millstein, I. M. and S. M. Katsh: 1981, The Limits of Corporate Power (New York).

Pigou, A. C.: 1920 (1962), The Economics of Welfare, 4th Edition (MacMillan, New York).

Polanyi, K.: 1944, The Great Transformation (Rinehart and Company, New York).

Scherer, F. M.: 1994, Competition Policies for an Integrated World Economy (Washington, DC).

Scherer, A. G., G. Palazzo and D. Baumann: 2006, 'Global Rules and Private Actors: Toward a New Role of the Transnational Corporation in Global Governance', Business Ethics Quarterly 16(4), 505-532.

SER: 2002, Innovatie voor Duurzaam Voedsel en Groen (SER, The Hague).

SER: 2003, Evaluatie en Aanpassing Mededingingswet (SER, The Hague).

Smith, A.: 1776 (1976), in R. H. Campbell and A. S. Skinner (eds.), An Inquiry into the Nature and Causes of the Wealth of Nations. Two Volumes (Oxford University Press, Oxford).

SNM: 2003, Een Eerlijke Prijs voor Duurzaam Voedsel (SNM, Utrecht).
SNM: 2004, People, Planet, Profit in the Supermarkt: Inspirerende Voorbeelden uit Binnen- en Buitenland van Verantwoord Ondernemen in Supermarkten (SNM, Utrecht).

van Luijk, H.: 2000, 'Multinationele Ondernemingen Zouden Moeten ...', Filosofie in Bedriff 33, 16-27.

Vedder, A. (ed.): 2003, The WTO and Concerns Regarding Animals and Nature (Wolf) Tilburg.

Vliet, M. van: 1992, Communicative Besturing van het Milieuhandelen van Ondernemingen (Eburon) Delft.

Weber, M.: 1921 (1972), Wirtschaft und Gesellschaft. Grundriss der verstehenden Soziologie, 5th Edition, Studienausgabe (J.C.B. Mohr, Tübingen).

Wim Dubbink

Business Ethics and Political Economy, Tilburg University, P.O. Box 90153, 5000 LE Tilburg,

The Netherlands

E-mail:w.dubbink@uvt.nl

Frans Paul van der Putten Clingendael Asia Studies/Security E Conflict Programme, Netherlands Institute of International Relations, P.O. Box 93080, 2509 AB The Hague, The Netherlands E-mail:fputten@clingendael.nl 